\title{
Pengaruh Penambahan Daging Buah Naga Super Merah (Hylocereus Costaricensis) Terhadap Kualitas Nata De Coco yang Dihasilkan
}

\author{
Hamka* \\ Sri Amanah \\ Teknologi Hasil Perkebunan, \\ Politeknik Pertanian Negeri \\ Samarinda-Indonesia \\ hamka@politanisamarinda. \\ ac.id \\ *Corresponding author \\ Teknologi Hasil Perkebunan, \\ Politeknik Pertanian Negeri \\ Samarinda-Indonesia \\ amahamanah97@gmail.com
}

\author{
Marwati \\ Teknologi Hasil Pertanian, \\ Universitas Mulawarman- \\ Indonesia \\ marwatiwawa.unmul \\ @gmail.com
}

\author{
Eva Nurmarini \\ Pengolahan Hasil Hutan, \\ Politeknik Pertanian Negeri \\ Samarinda-Indonesia \\ evapriansyah10@yahoo.co.id
}

\begin{abstract}
Abstrak-Tanaman kelapa merupakan salah satu tanaman perkebunan yang memiliki manfaat besar bagi kehidupan manusia yang saat ini belum dimanfaatkan secara optimal. Salah satu upaya untuk meningkatkan kualitas komoditi kelapa yaitu dengan memanfaatkan air kelapa sebagai bahan baku pembuatan Nata de Coco yang ditambahkan daging buah naga super merah sebagai pewarna alami. Penelitian ini menggunakan rancangan acak lengkap (RAL), dengan 3 kali ulangan untuk penambahan daging buah naga dengan konsentrasi $0 \%, 15 \%, 30 \%$, dan $45 \%$ pada pembuatan Nata de Coco tersebut. Parameter yang diuji adalah uji ketebalan, uji derajat keasaman $(\mathrm{pH})$ dan uji organoleptik terhadap warna, aroma, rasa, dan tekstur. Hasil penelitian menunjukkan perbedaan nyata terhadap nilai $\mathrm{pH}$, ketebalan, serat kasar dan uji organoleptik terhadap aroma, rasa serta tekstur. Penambahan daging buah naga super merah 10\% mendekati control (tanpa penambahan daging buah super merah, $0 \%$ ) dengan nilai pH 3,65; ketebalan $0,48 \mathrm{~cm}$; kadar serat $6,11 \%$ dan nilai organoleptik warna (agak suka), aroma (agak suka), rasa (suka) dan tekstur (suka).
\end{abstract}

Kata kunci: nata de coco, daging buah naga merah,

\section{PENDAHULUAN}

Tanaman kelapa (Cocos nucifera L.) merupakan salah satu tanaman yang paling sering dilihat dan dijumpai di seluruh kawasan tropis (Winarno, 2014). Indonesia merupakan negara beriklim tropis sehingga sangatlah mudah dijumpai tanaman kelapa ini, apalagi tanaman kelapa ini mudah tumbuh diberbagai jenis tanah dan tahan dari berbagai cuaca. Meskipun tumbuhan kelapa sangat bermanfaat bagi kehidupan manusia tetapi nyatanya komoditi perkebunan ini belum dimanfaatkan secara optimal dan masih kurangnya perhatian pemerintah. Berbeda sekali dengan komoditi perkebunan lainnya yang sangat diperhatikan sepenuhnya dengan pemerintah seperti komoditi kelapa sawit, lada dan kopi (Winarno, 2014). Salah satu upaya untuk meningkatkan kualitas komoditi perkebunan kelapa yaitu dengan usaha memanfaatkan seluruh bagian dari komoditi kelapa seperti mengoptimalkan pemanfaatan air kelapa sebagai bahan baku pembuatan Nata de Coco. Nata adalah produk pangan yang berbahan dasar air kelapa yang menyerupai jelly kenyal berwarna putih susu atau bening melaui proses fermentasi. Proses fermentasi air kelapa di bantu dengan sejenis bakteri yang bernama Acetobacter xylinum (Sihmawati dkk, 2014). Menurut Suraya, (2017) Nata de Coco yang beredar pada umumnya berwarna putih, bertekstur tebal dan kenyal serta tidak berasa. Hingga kini, belum begitu banyak produsen yang memberikan pewarna pada produk Nata de Coco. Pemanfaatan buah naga super merah sebagai pewarna telah diaplikasikan pada beberapa produk pangan karena memiliki nutrisi dan warna yang eksotis seperti permen jelly (Hamka dkk, 2020). Penambahan daging buah naga pada nata decoco diharapkan dapat memberikan warna alami yang baik untuk kesehatan. Sehingga dapat menggantikan pewarna makanan pada Nata de Coco (sesuai SNI 01-0222-1995).

\section{TUJUAN PENELITIAN}

Tujuan dari penelitian adalah untuk mengetahui pengaruh penambahan daging buah naga super merah terhadap kualitas nata de coco dan mendapatkan jumlah penambahn daging buah naga super merah yang tepat dalam menghasilkan nata de coco. 


\section{METODE PENELITIAN}

\section{A. Bahan dan Alat}

Alat yang digunakan dalam pembuatan Nata De Coco adalah timbangan analitik, gelas beker, spatula, sendok, panci, teko ukur, pisau, saringan, tissue, loyang plastik, koran, dan karet gelang sedangkan alat yang digunakan untuk analisis ketebalan, derajat keasaman $(\mathrm{pH})$, uji organoleptik, uji kadar serat kasar adalah penggaris, $\mathrm{pH}$ meter, piring, pulpen kertas, hotplate, erlenmeyer, kertas saring, timbangan analitik, spatula, pipet volume, memert, desikator, corong, gelas beker, pendingin balik/kondensor.

Bahan yang digunakan dalam pembuatan Nata De Coco adalah starter (bakteri Acetobacter xylinum) diperoleh dari Laboratorium Mikrobiologi Perkebunan-Politani Samarinda, air kelapa, gula, cuka, urea, NPK, asam sitrat, dan buah naga. Sedangkan bahan yang digunakan yaitu $\mathrm{H}_{2} \mathrm{SO}_{4}, \mathrm{NaOH}$, dan alkohol $96 \%$.

\section{B. Pelaksanaan Penelitian}

Penelitian ini dilakukan di Laboratorium Mikrobiologi, Program Studi Teknologi Hasil Perkebunan, Politeknik Pertanian Negeri Samarinda. Penelitian ini menggunakan Rancangan Acak Lengkap (RAL) dengan 1 faktor yaitu penambahan daging buah naga merah, yang terdiri dari $0 \%$ (kontrol, tanpa penambahan daging buah naga super merah), $15 \%$, $30 \%$ dan $45 \%$. Setiap perlakuan diulang sebayak tiga kali. Parameter pengamatan meliputi pH (Apriyantono dkk., 1989), kadar serat (Sudarmadji, dkk., 1997), ketebalan diukur dengan menggunakan jangka sorong. Penilaian organoleptik dengan uji kesukaan dilakukan oleh 25 orang panelis semi terlatih pada skala hedonik 1-5 yaitu 1 (sangat tidak suka), 2(tidak suka), 3 (agak suka), 4 (suka) dan 5 (sangat suka) (Soekarto, 1981).

Prosedur pembuatan Nata de Coco mengacu pada Sihmawati, dkk (2014) yang telah dimodifikasi sebagai berikut:

1. Air kelapa disaring sebanyak 1 liter agar terpisah dari kotoran, kemudian dipanaskan hingga mendidih.

2. Ditambahkan gula sebanyak 10 gram, cuka asam sebanyak $10 \mathrm{ml}$, urea sebanyak 0,7 gram, NPK sebanyak 1,7 gram, dan asam sitrat sebanyak 0,7 gram kemudian diaduk hingga homogen tetapi tetap dalam keadaan dipanaskan.

3. Buah naga dikupas dan dagingnya dilumatkan menjadi puree kemudian dicampurkan dengan air kelapa sesuai perlakuan. Didinginkan selama 24 jam kemudian ditambahkan starter sebanyak $10 \%$.

4. Dituang ke dalam loyang plastik steril dan ditutup dengan kertas dan diikat dengan karet gelang, selanjutnya difermentasi selama 10 hari.
5. Nata de Coco dipanen dengan cara dicuci sampai bersih dan dipotong dengan ukuran $1 \mathrm{~cm}^{2}$.

6. Selanjutnya dilakukan perebusan selama 5 menit pada air mendidih dan dilakukan sebanyak tiga kali. Dan dilanjutkan dengan perebusan dengan larutan gula dengan komposisi 250 gram gula dalam 1 liter air.

\section{HASIL DAN PEMBAHASAN}

\section{A. Derajat keasaman $(\mathrm{pH})$}

Hasil pengujian nilai $\mathrm{pH}$ pada Nata de Coco dengan penambahan daging buah naga dengan konsentrasi yang berbeda ditampilkan dalam gambar 1 . Hasil analisis sidik ragam menunjukkan bahwa penambahan daging buah naga super merah berpengaruh nyata terhadap $\mathrm{pH} \mathrm{Nata}$ de Coco yang dihasilkan. Penambahan daging buah super naga merah dengan konsentrasi $0 \%$ (tanpa penambahan buah naga) tidak berbeda nyata dengan penambahan $15 \%$ tetapi berbeda nyata dengan penambahan $30 \%$ dan $45 \%$.

Tingkat Keasaman pada substrat juga berpengaruh terhadap pertumbuhan bakteri untuk membentuk lembaran nata. Bakteri Nata de Coco dapat hidup pada larutan dengan derajat keasaman atau kebasaan pada $\mathrm{pH} 3,57-3,77$. Hal ini sesuai dengan kemampuan bakteri Acetobacter xylinum pada $\mathrm{pH}$ 3,57,5 (Pambayun, 2002).

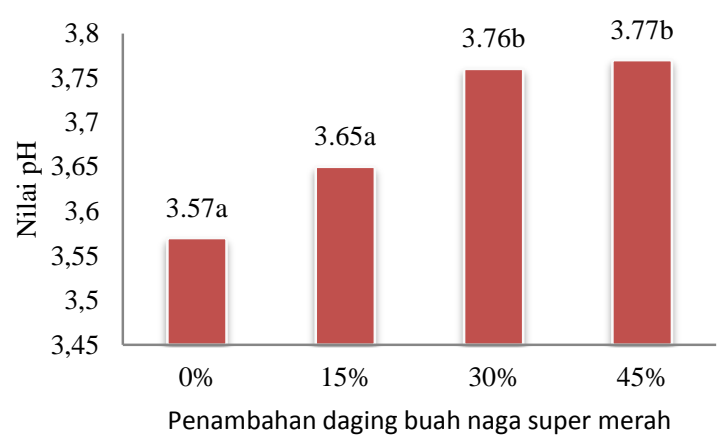

Gambar 1. Hasil uji BNT terhadap nilai pH pada Nata de Coco dengan konsentrasi penambahan daging buah naga yang berbeda.

Keterangan : skala hedonik 1-5 yaitu 1 (sangat tidak suka), 2(tidak suka), 3 (agak suka), 4 (suka) dan 5 (sangat suka)

Hasil yang diperoleh dari uji $\mathrm{pH}$ menunjukkan semakin tinggi konsentrasi penambahan daging buah naga merah maka semakin tinggi nilai $\mathrm{pH}$ pada nata. Nilai $\mathrm{pH}$ terendah terdapat pada konsentrasi penambahan daging buah naga sebanyak $0 \%$ (kontrol) yaitu sebesar 3,57 sedangkan nilai $\mathrm{pH}$ tertinggi 
terdapat pada konsentrasi penambahan daging buah naga sebesar $45 \%$ yaitu sebesar 3,77.

B. Ketebalan

Hasil pengujian ketebalan pada Nata de Coco dengan penambahan daging buah naga dengan konsentrasi yang berbeda disajiakn gambar 2. Hasil analisis sidik ragam menunjukkan bahwa penambahan daging buah naga super merah memberikan pengaruh terhadap ketebalan Nata de Coco yang dihasilkan. Semakin tinggi persentase penambahan daging buah naga super merah semakin berkurang ketebalan pada Nata de Coco yang dihasilkan.

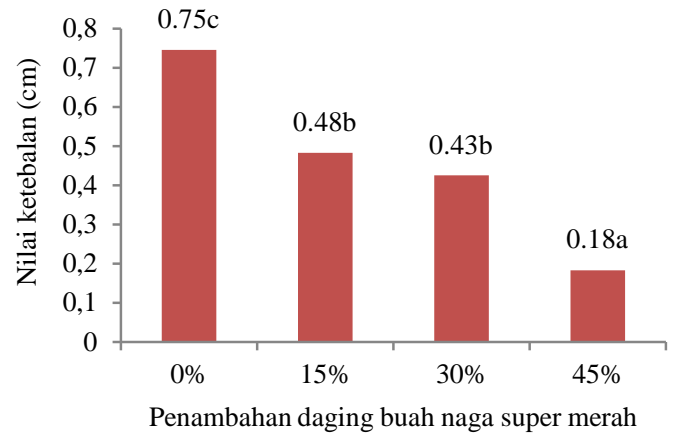

Gambar 2. Hasil uji BNT terhadap Uji Ketebalan pada Nata de Coco dengan konsentrasi penambahan daging buah naga yang berbeda.

Keterangan : skala hedonik 1-5 yaitu 1 (sangat tidak suka), 2(tidak suka), 3 (agak suka), 4 (suka) dan 5 (sangat suka)

Hal tersebut diduga karena ketidakmampuan bakteri mengubah substrat menjadi benang-benang selulosa yang dipengaruhi oleh sumber makanan bakteri Acetobacter xylinum dan sumber karbon sehingga terdapat sisa substrat yang tidak terombak oleh bakteri. Air kelapa adalah media yang paling tepat untuk menghasilkan nata decoco dengan ketebalan yang sesuai. Penambahan daging buah naga super merah menyebabkan jumlah air kelapa yang menjadi media optimal pertumbuhannya berkurang. Pengunaan air kelapa sangat cocok untuk pertumbuhan Acetobacter xylinum karena memilki nutrisi seperti protein, karbohidrat dan beberapa mineral. Kandungan karbohidrat pada air kelapa sebagai sumber karbon dalam bentuk sukrosa, glukosa, fruktosa, sorbitol dan inositol (Setiaji dkk, 2002)

\section{Serat Kasar}

Hasil pengujian kadar serat kasar pada Nata de Coco dengan penambahan daging buah naga dengan konsentrasi yang berbeda disajikan pada gambar 3 .

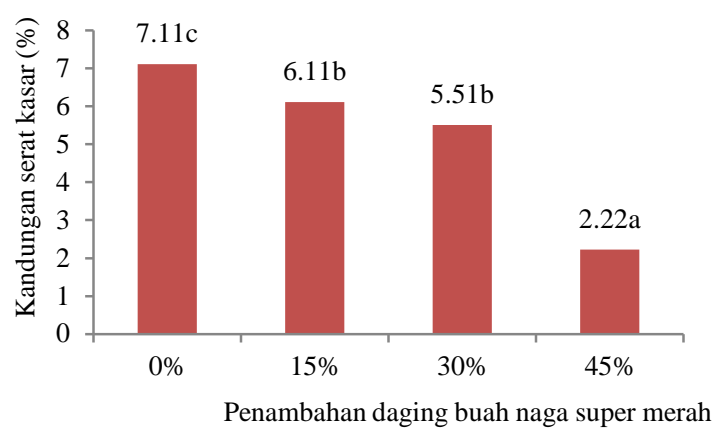

Gambar 3. Hasil uji BNT terhadap Uji Ketebalan pada Nata de Coco dengan konsentrasi penambahan daging buah naga yang berbeda.

Keterangan : skala hedonik 1-5 yaitu 1 (sangat tidak suka), 2(tidak suka), 3 (agak suka), 4 (suka) dan 5 (sangat suka)

Penambahan daging buah naga super merah menurunkan jumlah kandungan serat pada nata de coco. Hal ini berhubungan dengan ketebalan yang dihasilkan. Dibandingkan dengan kontrol (tanpa penambahan daging buah naga super merah) memberikan ketebalan yang lebih besar dengan kandungan serat yang lebih tinggi. Hal ini berhubungan dengan berkurangnya air kelapa yang merupakan media yang sesuai karena digantikan oleh daging buah naga seuper merah.

\section{Nilai Organoleptik}

1. Warna

Kesukaan panelis terhadap warna berada pada kisaran nilai 2,77 hingga 3,67. Hal ini berarti nilai kesukaan terhadap warna masuk kepada kriteria "agak suka sampai suka". Nilai kesukaan warna ditampilkan pada gambar 4 .

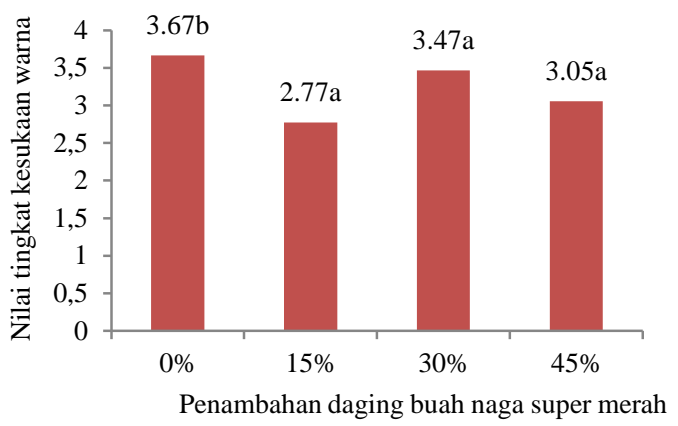

Gambar 4. Nilai rata-rata uji organoleptik warna pada Nata de Coco dengan konsentrasi penambahan daging buah naga yang berbeda.

Keterangan : skala hedonik 1-5 yaitu 1 (sangat tidak suka), 2(tidak suka), 3 (agak suka), 4 (suka) dan 5 (sangat suka) 
Penambahan buah naga super merah memberikan pengaruh terhadap warna Nata de Coco. Tanpa penambahan daging buah naga super merah (0\%, kontrol) berbeda nyata dengan penambahan daging buah naga super merah $15 \%$, $30 \%$ dan $45 \%$, tetapi penambahan tersebut tidak berbeda nyata. Panelis memberikan penilaian kesukaan yang lebih tinggi pada kontrol dibandingkan dengan perlakuan lain (penambahan daging super merah $15 \%, 30 \%$ dan $45 \%$ ). Hal ini disebabkan karena warna yang dihasilkan berubah pada saat perebusan. Selama perebusan warna merah Nata de Coco larut sehingga warna menjadi tidak menarik.

2. Aroma

Tingkat kesukaan panelis terhadap aroma (gambar 5), menunjukkan bahwa penambahan daging buah naga super merah berpengaruh yang nyata. Semakin tinggi penambahan daging buah naga super merah maka panelis memberikan penilaian tingkat kesukaan yang tinggi. Hal ini disebabkan oleh buah naga super merah yang memiliki aroma khas yang dapat menutupi aroma asli dari Nata de Coco yang beraroma asam.

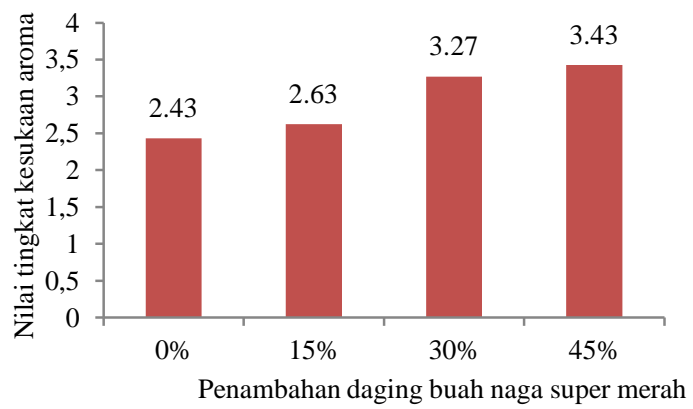

Gambar 5. Nilai rata-rata uji organoleptik aroma pada Nata de Coco dengan konsentrasi penambahan daging buah naga yang berbeda.

Keterangan : skala hedonik 1-5 yaitu 1 (sangat tidak suka), 2(tidak suka), 3 (agak suka), 4 (suka) dan 5 (sangat suka)

3. Rasa

Hasil penilaian Kesukaan rasa dari panelis tersaji pada gambar 6. Penambahan daging buah naga super merah pada Nata de Coco memberikan nilai terhadap rasa lebih disukai. Hal ini berbanding lurus dengan tingkat kesukaan pada aroma yang juga disukai dengan adanya penambahan daging buah naga super merah. Rasa merupakan indikator sensoris yang paling menetukan tingkat penerimaan.
Rasa suka yang diberikan panelis menunjukkan bahwa buah naga super merah memberikan pengaruh terhadap rasa pada nata de coco. Hal ini memenuhi Syarat Mutu Nata dalam Kemasan (SNI 01 - 4317, 1996) yaitu normal.

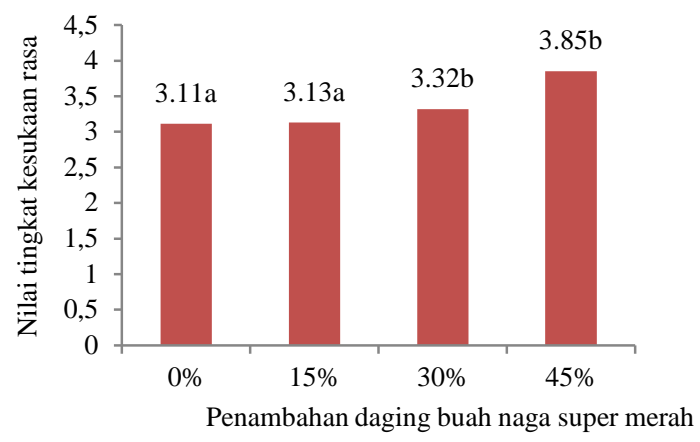

Gambar 6. Nilai rata-rata uji organoleptik aroma pada Nata de Coco dengan konsentrasi penambahan daging buah naga yang berbeda.

Keterangan : skala hedonik 1-5 yaitu 1 (sangat tidak suka), 2(tidak suka), 3 (agak suka), 4 (suka) dan 5 (sangat suka)

4. Tekstur

Respon panelis terhadap tekstur disukai. Hal ini memenuhi syarat mutu nata dalam Kemasan (SNI 01 - 4317, 1996) yaitu normal. Tekstur pada nata de coco yang ideal adalah yang kenyal. Nilai hedonik tekstur pada Nata de Coco ditampilkan pada gambar 7 .

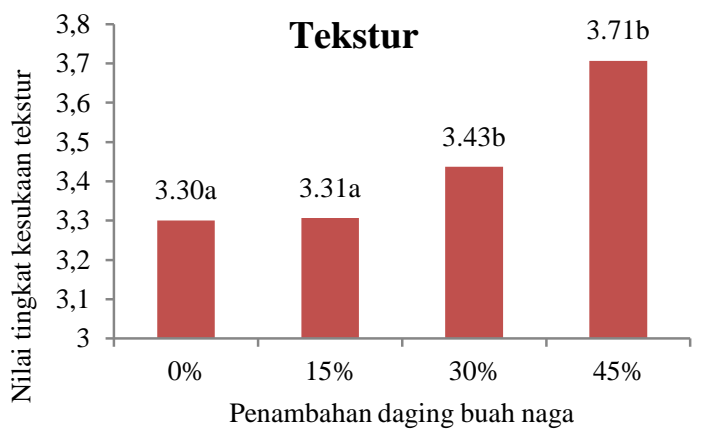

Gambar 7. Nilai rata-rata uji organoleptik aroma pada Nata de Coco dengan konsentrsi penambahan daging buah naga yang berbeda.

Keterangan: skala hedonik 1-5 yaitu 1 (sangat tidak suka), 2(tidak suka), 3 (agak suka), 4 (suka) dan 5 (sangat suka) 


\section{https://doi.org/10.51967/tanesa.v22i1.459 $\quad$ (C) 2021 Politeknik Pertanian Negeri Samarinda Karya ini dilisensikan di bawah Lisensi Creative Commons Attribution 4.0}

\section{KESIMPULAN}

Hasil penelitian menunjukkan bahwa penambahan daging buah naga super merah memberikan pengaruh terhadap $\mathrm{pH}$, ketebalan, serat kasar, dan nilai organoleptik. Penambahan daging buah naga super merah $10 \%$ mendekati control (tanpa penambahan daging buah super merah, 0\%) dengan nilai $\mathrm{pH} 3,65$; ketebalan $0,48 \mathrm{~cm}$; kadar serat $6,11 \%$ dan nilai organoleptik warna (agak suka), aroma (agak suka), rasa (suka) dan tekstur (suka).

\section{DAFTAR PUSTAKA}

Apriyantono, A., D. Fardiaz, N. L. Puspitasari, Sedarmawati, dan S. Budiyanto. 1989. Petunjuk Laboratorium Analisa Pangan. Bogor: Pusat Antar Universitas Pangan dan Gizi Institut Pertanian Bogor.

Badan Standardisasi Nasional. (1996). Standar Nasional Indonesia: Syarat Mutu Nata De coco dalam kemasan SNI 01 - 4317, 1996 Jakarta. Badan Standardisasi Nasional.

Hamka, Nurita, Marwati dan E. Nurmarini. 2020. Sifat Kimia dan Organoleptik Jelly Buah Naga (Hylocereus polyrhizus) dengan Penambahan Karagenan Sebagai Gelling Agent. Buletin LOUPE Volume 16 No 1.

Pambayun. R. 2002. Teknologi Pengolahan Nata De Coco. Kanisius. Yogyakarta. Hal $13-20$.

Setiaji, B., A. Setyopratiwi, and N. Cahyandaru. 2002. "Peningkatan nilai tambah skim santan kelapa limbah pembuatan minyak kelapa sebagai substrat nata de coco." Indonesia Journal of Chemistry 2.3.pp. 167-172.

Sihmawati, R.R., Devy O., Wardah. 2014. Jurnal Mutu Produk Nata De Coco dengan Penambahan Sari Buah Mangga. Universitas Tujuh belas Agustus. Surabaya. Vol 11. No 2.

Soekarto. ST., 1981. Penilaian Organoleptik. Pusat Pengembangan Teknologi Pangan (Pusbangtepa). Institut Pertanian Bogor. Bogor.

Sudarmadji S., Haryono B., Suhardi., 1997. Prosedur Analisa untuk Bahan Pangan dan Pertanian. Liberty. Yogyakarta. Hal $40-41$.

Soekarto ST. 1985. Penilaian Organoleptik untuk Industri Pangan dan Hasil Pertanian. Jakarta: Bhratara Karya Aksara.
Suraya, ID. 2017. Pengaruh Penambahan Kulit Buah Naga Merah Dalam Proses Pembuatan Nata De Coco Terhadap Mutu Fisik Nata. Program Studi Teknologi Pangan Fakultas Peternakan dan Pertanian Universitas Diponegoro. Semarang.

Winarno. F.G.2014. Kelapa Pohon Kehidupan. Gramedia Pustaka Utama. Jakarta. Hal. xii -8 . 